\title{
Effect of inulin addition on the physicochemical, microbiological, and sensory characteristics from guava-flavored petit-suisse kefir cheese
}

\author{
Efeito da adição de inulina nas características físico-químicas, microbiológicas e sensoriais do \\ queijo petit-suisse de kefir sabor goiaba \\ Efecto de la adición de inulina sobre las características fisicoquímicas, microbiológicas y sensoriales \\ del queso de kéfir petit-suisse con sabor a guayaba
}

Poliana Brito de Sousa

ORCID: https://orcid.org/0000-0003-1037-8747 Instituto Federal de Educação, Ciência e Tecnologia do Piauí, Brazil E-mail: pollysousa100@gmail.com

Thays Lima Fama Guimarães ORCID: https://orcid.org/0000-0003-3644-8811 Instituto Federal de Educação, Ciência e Tecnologia do Ceará, Brazil E-mail: thaysfama@hotmail.com

Priscila Luana da Silva ORCID: https://orcid.org/0000-0002-1655-7394 Instituto Federal de Educação, Ciência e Tecnologia do Ceará, Brazil E-mail: priscilaluanaspfc@gmail.com

Everlândia Silva Moura Miranda

ORCID: https://orcid.org/0000-0002-2671-7005 Instituto Federal de Educação, Ciência e Tecnologia do Ceará, Brazil E-mail: everlandiamoura7@yahoo.com

Elisangela de Andrade Castro ORCID: https://orcid.org/0000-0002-1618-927X Instituto Federal de Educação, Ciência e Tecnologia do Ceará, Brazil E-mail: elisangelaandrade@ifce.edu.br

Érica da Costa Monção

ORCID: https://orcid.org/0000-0002-4334-5338 Instituto Federal de Educação, Ciência e Tecnologia do Maranhão, Brazil E-mail: ericaalimentos@gmail.com

Sandra Maria Lopes dos Santos ORCID: https://orcid.org/0000-0001-9342-3931

Faculdade de Tecnologia CENTEC, Brazil E-mail: anisulivan@gmail.com

Luana Guabiraba Mendes

ORCID: https://orcid.org/0000-0001-8184-8588 Instituto Federal de Educação, Ciência e Tecnologia do Ceará, Brazil

E-mail: luanagmendes@gmail.com

Antônio Belfort Dantas Cavalcante ${ }^{1}$

ORCID: https://orcid.org/0000-0001-8440-2979 Instituto Federal de Educação, Ciência e Tecnologia do Ceará, Brazil

E-mail: belfort.dantas@ifce.edu.br

Marlene Nunes Damaceno

ORCID: https://orcid.org/0000-0002-3553-6740 Instituto Federal de Educação, Ciência e Tecnologia do Ceará, Brazil E-mail: marlene@ifce.edu.br

\begin{abstract}
This study aimed to prepare guava-flavored petit-suisse kefir cheese with inulin and to evaluate the physicochemical, microbiological, and sensory characteristics of the product in refrigerated storage. Preliminary assays were carried out to adjust the ingredients by selecting two formulations to add inulin at 3\% and $6 \%$ concentrations and compare with the control (without inulin). Physicochemical analyses (acidity, $\mathrm{pH}$, water activity, vitamin $\mathrm{C}$, lycopene, fructans, ash, proteins, fat, moisture, carbohydrates, calories, color, and viscosity) microbiological (total and thermotolerant coliforms, Salmonella spp., lactic acid bacteria, acetic acid bacteria, and yeasts) at 1,14 and 28 days of storage at $4{ }^{\circ} \mathrm{C}$, and sensory at the initial and final times. The results were submitted to ANOVA and Tukey test $(\mathrm{p}<0.05)$. The addition of inulin significantly altered the physicochemical characteristics except for moisture, water activity, ash, proteins, and
\end{abstract}


carbohydrates. The samples had good hygiene-sanitary conditions, which was confirmed by the absence of total and thermotolerant coliforms, and a reduction in the number of lactic acid bacteria, acetic acid bacteria, and yeast was observed in the final storage time. Sensory attributes, such as flavor, overall impression, and purchase intention, were also influenced by the concentration of inulin, except for appearance, aroma, and texture. All the samples presented an Acceptability Index above $70 \%$ for most sensory attributes in the final storage time. The guava-flavored petit-suisse kefir cheese is likely to large-scale production, being a nutritious food with good microbiological quality and sensory until 28 days of storage.

Keywords: Acceptance; Dairy dessert; Fermented milk; Fructans; Psidium guajava L.

\section{Resumo}

O objetivo deste estudo foi elaborar queijo petit-suisse de kefir sabor goiaba com inulina e avaliar as características físico-químicas, microbiológicas e sensoriais do produto em armazenamento refrigerado. Ensaios preliminares foram realizados para ajuste dos ingredientes selecionando-se duas formulações para adicionar inulina nas concentrações $3 \%$ e $6 \%$ e comparar com a controle (sem inulina). Foram realizadas análises físico-químicas (acidez, pH, atividade de água, vitamina C, licopeno, frutanos, cinzas, proteínas, gordura, umidade, carboidratos, valor calórico, cor e viscosidade) microbiológicas (coliformes totais e termotolerantes, Salmonella spp., bactérias ácido-lácticas, bactérias ácido-acéticas e leveduras) nos tempos 1,14 e 28 dias de estocagem a $4{ }^{\circ} \mathrm{C}$, e sensoriais nos tempos inicial e final. Os resultados foram submetidos a ANOVA e teste de Tukey $(\mathrm{p}<0,05)$. A adição de inulina alterou significativamente as características físicoquímicas exceto para umidade, atividade de água, cinzas, proteínas e carboidratos. As formulações apresentavam boas condições higiênico-sanitárias, o que foi comprovado pela ausência de coliformes totais e termotolerantes e foi observada redução do número de bactérias ácido-láticas, bactérias ácido acético e leveduras ao final do armazenamento. Atributos sensoriais, como sabor, impressão global e intenção de compra, também foram influenciados pela concentração de inulina, exceto aparência, aroma e textura. Todas as formulações apresentaram Índice de Aceitabilidade superior a $70 \%$ para a maioria dos atributos sensoriais no tempo final de armazenamento. O queijo petit-suisse de kefir sabor goiaba com inulina apresenta grande probabilidade de produção em larga escala, sendo um alimento nutritivo e de boa qualidade microbiológica e sensorial até 28 dias de armazenamento.

Palavras-chave: Aceitação; Sobremesa láctea; Leite fermentado; Frutanos; Psidium guajava L.

\section{Resumen}

El objetivo de este estudio fue preparar queso kéfir petit-suisse sabor guayaba con inulina y evaluar las características fisicoquímicas, microbiológicas y sensoriales del producto en almacenamiento refrigerado. Se llevaron a cabo ensayos preliminares para ajustar los ingredientes seleccionando dos formulaciones para agregar inulina a concentraciones de $3 \%$ y $6 \%$ y comparar con el control (sin inulina). Se realizaron análisis fisicoquímicos (acidez, $\mathrm{pH}$, actividad del agua, vitamina C, licopeno, fructanos, cenizas, proteínas, grasa, humedad, carbohidratos, calorías, color y viscosidad) microbiológicos (coliformes totales y termotolerantes, Salmonella spp., bacterias del ácido láctico, bacterias del ácido acético y levaduras) a 1,14 y 28 días de almacenamiento a $4{ }^{\circ} \mathrm{C}$, y sensoriales en los tiempos inicial y final. Los resultados se sometieron a ANOVA y prueba de Tukey $(\mathrm{p}<0.05)$. La adición de inulina cambió significativamente las características fisicoquímicas a excepción de la humedad, la actividad del agua, las cenizas, las proteínas y los carbohidratos. Las muestras tuvieron buenas condiciones higiénico-sanitarias, lo que se confirmó por la ausencia de coliformes totales y termotolerantes y se observó una reducción en el número de bacterias del ácido láctico, bacterias del ácido acético y levaduras al final del almacenamiento. Los atributos sensoriales como el sabor, la impresión general y la intención de compra también se vieron influenciados por la concentración de inulina, pero la apariencia, el aroma y la textura no. Todas las muestras presentaron un índice de aceptabilidad superior al 70\% para la mayoría de los atributos sensoriales en el tiempo de almacenamiento final. El queso kéfir petit-suisse sabor guayaba con inulina es altamente aceptado en una producción a gran escala, siendo un alimento nutritivo con buena calidad microbiológica y sensorial hasta por 28 días de almacenamiento

Palabras clave: Aceptación; Postre lácteo; Leche fermentada; Fructanos; Psidium guajava L.

\section{Introduction}

Food industries have been more and more worried about launching both attractive and quality products, aiming not only at health but also at consumer welfare. Among such foods, some may be considered functional, given their physiological benefits and/or ability to reduce the risk of chronic diseases (Cruz-Guerrero et al., 2014).

Two classes of food deserve highlighting among functional foods: probiotics and prebiotics. Probiotics are "live microorganisms which confer health benefits to the host when administrated in adequate amounts" (Sanders, 2008; Hossain, Sadekuzzaman \& Ha, 2017; Khaneghah et al., 2019).

Lactobacilli and Bifidobacterium are currently among the most used probiotics (Ku et al., 2020). Another alternative 
for consumption as a probiotic food is kefir, because it is fermented milk with recognized antibacterial, antifungal and antitumor activities, besides being able to promote benefits to immune and gastrointestinal systems and the metabolism of cholesterol. It is formed by a great number of bacterial strains and yeast that live symbiotically, both encapsulated by a polysaccharide matrix made by the bacteria (Farnworth, 2005; Lopitz-Otsoa, Rementeria, Elguezabal \& Garaizar, 2006; Ertekin \& Güzel-Seydim, 2010).

On the other hand, prebiotics are substrates used selectively by host microorganisms that confer a health benefit (Gibson et al., 2017; Quigley, 2018; Delzenne et al., 2019). Non-digestible carbohydrates such as polysaccharides (resistant starch, pectin, and dextrin) and oligosaccharides such as fructooligosaccharides (FOS), galactooligosaccharide (GOS), xylooligosaccharides (XOS), isomaltooligosaccharides (IMO), mannanoligosaccharides (MOS), raffinose oligosaccharides (RFOs), arabinoxylan-oligosaccharides (AXOS), lactulose, inulin, and others are considered food components with prebiotic properties (Mano et al., 2017; Mohanty, Misra, Mohapatra \& Sahu, 2018; Colantonio, Werner \& Brown, 2019; Farias, Araujo, Neri-Numa \& Pastore, 2019).

Inulin can increase the number of Bifidobacteria in the colon, acting beneficially on gastrointestinal functions (Roberfroid, 2005; Shoaib et al., 2016). Furthermore, they may be used as a substitute to sugar, fat, texture modifiers, hypocaloric volume, and texture-making agents (Cardarelli, Buriti, Castro \& Saad, 2008; Meyer, Bayarri, Tárrega \& Costell, 2011; Karimi, Azizi, Ghasemlou \& Vaziri, 2015; Shoaib et al., 2016).

The term 'symbiotic' refers to products that contain both probiotics and prebiotics. Strictly speaking, this term should be reserved for products in which the prebiotic component selectively favors the probiotic component (oligofructose and bifidobacteria), but not oligofructose with Lactobacillus (L) casei; however, if synergy is widely understood, this last combination is possible (Olveira \& González-Molero, 2016).

In addition to yogurts and fermented beverages, cheese is a good carrier to receive probiotic cultures and prebiotic ingredients. Several types, was highlight the petit-suisse cheese characterized, as fresh and smooth cheese with a texture that resembles a thick yogurt in most cases. Usually, this cheese is made of cow milk and can be salty or sweet when it is generally blended with fruits. Petit-suisse is known worldwide as one of the French soft cheeses with the greatest sensory acceptance by children, as well as by consumer groups of all ages (Esmerino et al., 2015; Bermudez-Beltrán, Marzal-Bolaño, OliveraMartínez \& Espitia, 2020).

Adding fruit to give flavor to petit-suisse cheese had been an industrial alternative to use such products, replacing synthetic flavors with healthier options. Guava (Psidium guajava L.) is an important fruit in tropical and subtropical areas (Forato, Britto, Rizzo, Gastaldi \& Assis, 2015; Santos et al., 2018) and an alternative to promote aroma, flavor, and color to this dairy dessert. It has high nutritional values and benefits to the organism, for being a good source of vitamin C, lycopene, potassium, copper, and fiber, in addition to having phytochemicals, such as tannins, flavonoids, and essential oils in their composition (Flores, Wu, Negrin \& Kennelly, 2015; Sanda, Grema, Geidam \& Bukar-Kolo, 2011).

The literature lacks information about petit-suisse kefir cheese, so this study aimed at assessing the effect of inulin upon the physicochemical, microbiological, and characteristics of guava-flavored petit-suisse kefir cheese during 28 days of storage at $4{ }^{\circ} \mathrm{C}$.

\section{Methodology}


This study corresponds to basic research of experimental nature and quantitative approach, classified as explanatory in terms of objectives, as it seeks to verify the cause and effect relationships of data collected in the laboratory (Cervo, Bervian \& Silva, 2007; Pereira, Shitsuka, Parreira \& Shitsuka, 2018).

\subsection{Processing guava-flavored petit-suisse kefir cheese, added with inulin}

To elaborate such product was carried out a three-step process: kefir elaboration, preparation of kefir dough, and last, elaboration of guava-flavored petit-suisse kefir cheese, added with inulin.

\subsubsection{Kefir elaboration}

For this process, the utensils and equipment were cleaned and sanitized with sodium hypochlorite following the manufacturer's recommendations. The lyophilized kefir grains (Fortaleza, Ceará, Brazil) were activated in UHT whole milk at $25^{\circ} \mathrm{C}$ for 48 hours. The proportion of $1 \mathrm{~g}$ of culture into $100 \mathrm{~mL}$ of milk was used. The culture was placed into a glass recipient, covered with a perforated cotton fabric up to the formation of a creamy curd. Afterward, was added milk to increase the culture volume. After this operation, the grains were filtered for further separation of the kefir drink, which was used to process the product.

\subsubsection{Preparation of kefir cheese dough}

The syneresis of kefir drink was conducted under refrigeration $\left(4^{\circ} \mathrm{C} / 12 \mathrm{~h}\right)$ by filtration in a cotton sieve, previously sterilized. The serum was discarded, and the dough was packed in plastic pots under refrigeration at $4{ }^{\circ} \mathrm{C} / 2 \mathrm{~h}$.

\subsubsection{Guava pulp preparation}

To obtain guava pulp, ripe guavas, variety 'Paluma', were selected, sanitized with sodium hypochlorite at $50 \mathrm{ppm} / 15$ minutes, and the pulps were removed manually. Afterward, were pasteurized in a water bath at $85^{\circ} \mathrm{C} / 5$ min, conditioned in 250 g plastic recipients, and cooled to $4^{\circ} \mathrm{C}$ for further use.

\subsubsection{Manufacture of guava-flavored petit-suisse kefir cheese, added with inulin}

To elaborate on the petit-suisse kefir cheese, the ingredients were weighed (kefir dough, guava pulp, carboxymethyl cellulose - CMC, sugar, and inulin). Afterward, mixed kefir dough with guava pulp in a domestic mixer until the mix was completely homogeneous (no visible lumps). After that, were added CMC, sugar, and inulin to the product, beating for 5 minutes. The result was conditioned to proper plastic recipients, sealed with plastic lids, and stored under refrigeration at $4{ }^{\circ} \mathrm{C}$.

Preliminary assays were run to adjust the ingredients, defining three formulations in accordance with the amount of inulin and sugar $(\mathrm{F} 0=0 \%$ and $14 \% ; \mathrm{F} 1=3 \%$ and $11 \% ; \mathrm{F} 2=6 \%$ and $8 \%)$, respectively, totalizing three treatments. Other ingredients added were standard: kefir cheese dough $=70 \%$; guava pulp $=15.8 \%$ and carboxymethyl cellulose $=0.2 \%($ Table 1). 
Table 1 - Formulations of guava-flavored petit-suisse kefir cheese with different concentrations of inulin.

\begin{tabular}{lrrr}
\hline \multirow{2}{*}{ Ingredients } & & Formulations*(\%) & F2 \\
\cline { 2 - 4 } & F0 & F1 & 70.0 \\
\hline Kefir dough & 70.0 & 70.0 & 15.8 \\
Guava pulp & 15.8 & 15.8 & 0.2 \\
Carboxymethylcellulose & 0.2 & 0.2 & 8.0 \\
Sugar & 14.0 & 11.0 & 6.0 \\
Inulin & 0.0 & 3.0 & 6 \\
\hline
\end{tabular}

*Abbreviations are: F0, guava-flavored petit-suisse kefir cheese (control treatment); F1, guava-flavored petit-suisse kefir cheese with 3\% of inulin and F2, guava-flavored petit-suisse kefir cheese with $6 \%$ of inulin. Source: Authors.

\subsection{Physicochemical analyses}

The physicochemical analyses were carried on the guava-flavored petit-suisse kefir cheese with inulin, following the recommendations of the Association of Official Analytical Chemists (2007).

The $\mathrm{pH}$ is determined using the electrometric method, acidity by titration with sodium hydroxide at $0.1 \mathrm{M}$ and phenolphthalein as indicator, fat by Gerber's method, protein by Kjeldahl's method, minerals, and moisture by gravimetry and carbohydrates by difference [100 - (moisture + minerals + proteins + lipids)]. The caloric value of 100 g-portion samples was calculated following the table of food composition. Was used Atwater conversion factors: $4 \mathrm{kcal} / \mathrm{g}$ (carbohydrates), $9 \mathrm{kcal} / \mathrm{g}$ (lipids), and $4 \mathrm{kcal} / \mathrm{g}$ (proteins).

Water activity was determined using Aqualab equipment (Decagon model $3 \mathrm{TE}$ ). Approximately $5 \mathrm{~g}$ of each sample were placed in a plastic recipient and the readings were made at a controlled temperature of $25^{\circ} \mathrm{C}$. Water activity was assessed following the device user guide.

For the instrumental color assessment, were used a colorimeter (brand MINOLTA CHROMA METER, CR-400), with the following specifications: reading area $11 \mathrm{~mm}$, illuminant CIE D65 (natural daylight), illumination at a $45^{\circ}$ angle, observation angle $0^{\circ}$, and standard observation CIE $196410^{\circ}$ (according to the Commission International for Illumination CIELAB). The readings of L (Luminosity), $a^{*}$ (red to green), and $b^{*}$ (yellow to blue) were carried out in triplicates.

The quantification of inulin content was carried out by using an enzymatic kit Fructan HK (from Megazyme HK Fructan kit, Megazyme, Bray, Ireland). In this method, sucrose and maltosaccharides with a low degree of polymerization (if present) are hydrolyzed to fructose and glucose, using a specific enzyme (sucrose/maltase). After pH adjustment, the samples were analyzed as to glucose + fructose (A) or were treated with fructanase (which hydrolyzes fructan into glucose and fructose) and then, analyzed as glucose + fructose (B). The concentration of glucose + fructose is measured with a system of hexokinase/phosphoglucose, isomerase/glucose 6-phosphate dehydrogenase. Thus, the content of fructans is determined by the difference between B and A.

To analyze viscosity, the samples were conditioned into a $600-\mathrm{mL}$ beaker and analyzed in the viscometer (brand Viscometer Brookfield, model DV II+) using spindle 4 at a 20-rpm speed (Irigoyen, Arana, Castiella, Torre \& Ibáñez, 2005) adapted, and temperature at $20^{\circ} \mathrm{C}$. The results were registered as centipascal (cPas).

\subsection{Microbiological analyses}

The microbiological assessment of the formulations studied based on the quantification of lactic bacteria, acetic bacteria, yeast, coliforms at $35^{\circ} \mathrm{C}$ (total), coliforms at $45^{\circ} \mathrm{C}$ (thermotolerant), and Salmonella sp.

To count the lactic acid bacteria, we used MRS medium (Acumedia) acidified with glacial acetic acid up to $\mathrm{pH} 5.4$ 
(Dave \& Shah, 1996). Inoculation was made by depth. The Petri dishes were incubated in jars containing an anaerobic atmosphere with the generator Anaerobac (PROBAC) at $30{ }^{\circ} \mathrm{C}$ for 72 hours in an incubator hothouse (Limatec).

The acetic acid bacteria were numbered in a selective medium prepared with $5 \%$ of glucose, $1 \%$ of yeast extract, and $2 \%$ of agar (Irigoyen et al., 2005). After sterilization at $121{ }^{\circ} \mathrm{C}$ for 15 minutes, we added $100 \mu \mathrm{g}$.mL ${ }^{-1}$ of penicillin to inhibit the growth of lactic acid bacteria. The inoculation was made by the depth and the Petri dishes were incubated in a hothouse (Limatec) at $30^{\circ} \mathrm{C}$ for 48 hours in an aerobic atmosphere.

The yeast counting was made in agar Yeast Extract Glucose Chloramphenicol (DifcoTM). Were added $20 \mathrm{~mL}$ of a culture medium (chloramphenicol yeast extract agar), incubated at a temperature of $25^{\circ} \mathrm{C}$ for 4 days in a hothouse (Limatec) (International Organization for Standardization [ISO]. International Dairy Federation [IDF], 2004). The results of counting lactic acid bacteria, acetic acid bacteria, and yeast were expressed as log CFU.g ${ }^{-1}$.

The analysis of total coliforms and thermotolerant expressed in MPN.g ${ }^{-1}$ and determination of the presence or absence of Salmonella sp. followed the methodology proposed by American Public Health Association (2001).

\subsection{Sensory analysis}

Guava-flavored petit-suisse kefir cheese formulations were subjected to sensory acceptance and purchase intention analyses. The test was realized into two times: 1 and 28 days of storage. Sensory analysis was performed in individual booths, under white lighting, with 120 untrained panelists (potential consumers of the product). For tasters considered the exposure of the research objectives, reading and signing the Informed Consent Formed authorizing their voluntary participation, as recommended by CNS Resolution No. 466/2012 when the research involves human beings (Brasil, 2013).

The three samples (approximately $25 \mathrm{~g}$ each) were served to consumers in monadic presentation and balanced order. The samples were coded with three-digit numbers and served with water and cookies for cleaning the taste.

For the affective tests, the consumers were requested to assess the following attributes: overall impression, appearance, aroma, texture, and flavor, using a structured 9-point hedonic scale ranging from 'dislike extremely' to 'like extremely' (Meilgaard, Carr \& Civille, 2015). To assess purchase intention, we used a structured 5-point scale with the following terms: (1) would certainly not buy; (2) would probably not buy; (3) might/might not buy; (4) would probably buy and (5) would certainly buy.

The Acceptability Index (AI) was calculated using the equation described by Dutcosky (2013), where IA = (average score obtained for the product/the highest score attributed to the product) x 100 .

\subsection{Statistical analyses}

For physicochemical and microbiological characterization, analysis of variance was performed in randomized designs with repetitions and measurements made three times $(1 ; 14$, and 28 days). The Tukey test at the 5\% level was used to compare the means. Statistical analyses were performed using the statistical software Assistat, version 7.7 beta (Silva, 2014).

\section{Results and Discussion}

\subsection{Physicochemical analyses}

Results show that adding inulin influenced neither the titratable acidity nor the water activity in any formulation ( $>0.05)$ (Table 2). The Brazilian law on petit-suisse cheese (Brazil, 2000) does not set forth values for such parameters. 
Table 2 - Physicochemical characteristics of guava-flavored petit-suisse kefir cheese with different concentrations of inulin, stored at $4 \pm 1{ }^{\circ} \mathrm{C}$.

\begin{tabular}{cccccccc}
\hline & & \multicolumn{5}{c}{ Average Values \pm Standard Deviation ** } \\
\cline { 3 - 7 } Formulations* & Days & $\begin{array}{c}\text { Acidity } \\
(\% \text { of lactic acid })\end{array}$ & $\mathrm{pH}$ & Water activity & $\begin{array}{c}\text { Vitamin C } \\
(\mathrm{mg} / 100 \mathrm{~g})\end{array}$ & $\begin{array}{c}\text { Lycopene } \\
(\mu \mathrm{g} / 100 \mathrm{~g})\end{array}$ & $\begin{array}{c}\text { Fructans } \\
(\%)\end{array}$ \\
\hline & 1 & $1.40 \pm 0.03^{\mathrm{aB}}$ & $4.00 \pm 0.00^{\mathrm{aA}}$ & $0.73 \pm 0.00^{\mathrm{aA}}$ & $6.06 \pm 0.97^{\mathrm{aB}}$ & $7.13 \pm 0.91^{\mathrm{bB}}$ \\
$\mathrm{F} 0$ & 14 & $1.49 \pm 0.03^{\mathrm{aB}}$ & $3.90 \pm 0.13^{\mathrm{aB}}$ & $0.72 \pm 0.02^{\mathrm{aA}}$ & $7.54 \pm 2.51^{\mathrm{aA}}$ & $9.96 \pm 1.04^{\mathrm{bA}}$ \\
& 28 & $1.50 \pm 0.07^{\mathrm{aB}}$ & $3.75 \pm 0.00^{\mathrm{aC}}$ & $0.73 \pm 0.04^{\mathrm{aA}}$ & $8.18 \pm 1.63^{\mathrm{aA}}$ & $8.18 \pm 0.55^{\mathrm{bB}}$ & \\
& 1 & $1.42 \pm 0.04^{\mathrm{aAB}}$ & $4.03 \pm 0.01^{\mathrm{abA}}$ & $0.73 \pm 0.00^{\mathrm{aA}}$ & $5.50 \pm 0.90^{\mathrm{aB}}$ & $6.78 \pm 0.26^{\mathrm{aB}}$ & $0.75 \pm 0.02^{\mathrm{bA}}$ \\
& 14 & $1.46 \pm 0.07^{\mathrm{aAB}}$ & $3.76 \pm 0.01^{\mathrm{abB}}$ & $0.74 \pm 0.01^{\mathrm{aA}}$ & $8.76 \pm 1.90^{\mathrm{aA}}$ & $12.82 \pm 2.05^{\mathrm{aA}}$ & - \\
& 28 & $1.51 \pm 0.07^{\mathrm{aAB}}$ & $3.73 \pm 0.01^{\mathrm{abC}}$ & $0.71 \pm 0.00^{\mathrm{aA}}$ & $8.14 \pm 0.81^{\mathrm{aA}}$ & $12.55 \pm 0.85^{\mathrm{aA}}$ & $0.04 \pm 0.03^{\mathrm{aB}}$ \\
& 1 & $1.46 \pm 0.05^{\mathrm{aA}}$ & $3.97 \pm 0.01^{\mathrm{bA}}$ & $0.73 \pm 0.00^{\mathrm{aA}}$ & $5.50 \pm 0.98^{\mathrm{aB}}$ & $9.05 \pm 0.37^{\mathrm{aB}}$ & $2.55 \pm 0.29^{\mathrm{aA}}$ \\
& 14 & $1.53 \pm 0.02^{\mathrm{aA}}$ & $3.76 \pm 0.01^{\mathrm{bB}}$ & $0.75 \pm 0.01^{\mathrm{aA}}$ & $8.94 \pm 0.82^{\mathrm{aA}}$ & $12.27 \pm 4.06^{\mathrm{aA}}$ & - \\
& 28 & $1.52 \pm 0.06^{\mathrm{aA}}$ & $3.71 \pm 0.02^{\mathrm{bC}}$ & $0.71 \pm 0.00^{\mathrm{aA}}$ & $9.40 \pm 4.06^{\mathrm{aA}}$ & $12.98 \pm 0.20^{\mathrm{aA}}$ & $0.13 \pm 0.02^{\mathrm{aB}}$ \\
\hline
\end{tabular}

*Abbreviations are: F0, guava-flavored petit-suisse kefir cheese (control treatment); F1, guava-flavored petit-suisse kefir cheese with $3 \%$ of inulin and F2, guava-flavored petit-suisse kefir cheese with $6 \%$ of inulin. **Averages $(n=3)$ followed by the same letter (uppercase) and (lowercase) in the column do not differ during the storage time and the formulations, respectively, according to Tukey test ( $>0.05$ ). Source: Authors.

It was also found that the $\mathrm{pH}$ decreased in all formulations (Table 2) during the final storage period ( $\mathrm{p}>0.05)$. Such reduction in $\mathrm{pH}$ values in cheese and other fermented products during storage is a natural process caused by the continuous production of lactic acids and other organic acids (Buriti, Rocha \& Saad, 2005; Kristo, Biliaderis \& Tzanetakis 2003).

Cardarelli et al. (2008) descript this $\mathrm{pH}$ reduction with values ranging between 4.55 and 4.25 and Prudencio, Prudêncio, Gris, Tomazi e Bordignon-Luiz (2008) ranging between 4.57 and 4.55. However, Modzelewska-Kapituła, Kłębukowska e Kornacki (2007) did not find significant differences in pH values among the formulations, nor between the storage times, when studying cheese added with Lactobacillus plantarum and inulin. The obtained results were inferior to those reported by Renhe et al. (2018) with a pH of 5.0 and 5.5, and Deolindo et al. (2019) observed that there was an increase in $\mathrm{pH}$ in the storage period from 3.58 to 4.02 .

As for vitamin $\mathrm{C}$ content, we verified that there was no significant difference ( $p>0.05)$ among the formulations, i.e., the different concentrations of added inulin did not influence this parameter. Vitamin $\mathrm{C}$ content varied from 5.50 to 9.40 $\mathrm{mg} / 100 \mathrm{~g}$. However, we observed that at time 1 , vitamin $\mathrm{C}$ content was lower $(\mathrm{p}<0.05)$ in all formulations, when compared with times 14 and 28 days of storage. The reason for such increase may be due to the production of such vitamins by microorganisms present in petit-suisse kefir cheese. According to Farnworth e Mainville (2008) vitamins, amino acids, and other essential factors for the growth of bacteria are produced by yeasts. Kefir contains vitamins A, B1, B2, B6, B12, C, D, E, Niacin, and Carotene (Ötles \& Cagindi, 2003). Sarkar (2007) states that the levels of vitamins are mainly influenced by the type of milk and the microbiota present in the grains.

When it comes to lycopene content, we observed that there was a significant difference among the formulations $(\mathrm{p}<0.05)$. Formulation F0 differed from the others (F1 and F2), having lower amounts in such parameters. Regarding the storage time except for F0, which remained with a low lycopene content, higher values ( $\mathrm{p}<0.05)$ were observed at 14 and 28 days for formulations with inulin (F1 and F2). Such increase in the content may be due to the production of carotenoids and, among them, lycopene, by microorganisms in the petit-suisse kefir cheese, since bacteria, fungi, and yeasts may biosynthesize such compounds (Schroeder \& Johnson 1995). 
As for fructan content, there was a significant difference among the formulations $(\mathrm{p}<0.05)$, considering the F2 presented the highest amounts and F1, the lowest (Table 2). Also was observed a decrease in inulin content during the storage times $(\mathrm{p}<0.05)$ for each formulation.

One of the likely causes for the reduction in inulin content may be related to the reduction in $\mathrm{pH}$ values of the formulations (Table 2). Once the inulin in this study had a pH between 5.0 and 7.0 (manufacturer information), also when it was added to the product, it was probably hydrolyzed, because the $\mathrm{pH}$ of the formulations was between 3.71 and 4.03 . The greater acidification of the medium probably contributed to the possible depolymerization of the fructan chains. In extremely acidic conditions $(\mathrm{pH}<4)$, the $\beta(2-1)$ bonds between fructose units can be partially hydrolyzed after storage, possibly leading to losses in physicochemical and functional properties (Charalampopoulos \& Rastall, 2012; Saito et al., 2019).

To consider food as prebiotic, the formulations must remain with the minimum amount set forth by law, which is $5 \mathrm{~g}$ in each $100 \mathrm{~g}$ of a solid product, until the end of the storage time (Brasil, 2016). The results evidenced that such formulations may not be considered prebiotic, because the contents varied from 0.04 to $2.55 \%$. A variation from $0.43 \%$ to $9.20 \%$ was observed by Cardarelli et al. (2008) while assessing the different combinations of inulin, oligofructose, and honey in formulations of symbiotic petit-suisse cheese. One way to solve the problem was to incorporate this prebiotic into new acidic products in greater proportions so that the product can achieve the threshold of functional property throughout its shelf life (Saito et al., 2019).

Ash content, moisture, carbohydrates, and calories suffered no influence by the addition of inulin or the storage time at $4{ }^{\circ} \mathrm{C}$ ( $\left.p>0.05\right)$ (Table 3). As for moisture content, the petit-suisse cheese may be classified as very highly moist cheese, when moisture is above 55\%. These data corroborate those by Ramírez-Santiago, Lobato-Calleros, Espinosa-Andrews e VernonCarter (2012), who observed moisture content ranging from 62 to $63 \%$ for low-fat petit-suisse cheese samples. Pereira et al. (2016) observed levels above $70 \%$ for petit-suisse probiotic cheese with the incorporation of antioxidants.

Table 3 - Chemical composition and caloric value of guava-flavored petit-suisse kefir cheese with different concentrations of inulin, stored at $4 \pm 1^{\circ} \mathrm{C}$.

\begin{tabular}{|c|c|c|c|c|c|c|c|}
\hline \multirow{2}{*}{$\begin{array}{c}\text { Formula } \\
\text { tions* }\end{array}$} & \multirow{2}{*}{$\begin{array}{c}\text { Storage } \\
\text { time } \\
\text { (Days) }\end{array}$} & \multicolumn{6}{|c|}{ Average Values \pm Standard Deviation $* *$} \\
\hline & & Ash (\%) & Proteins (\%) & Fat (\%) & Moisture (\%) & $\begin{array}{c}\text { Carbohydrates } \\
(\%)\end{array}$ & $\begin{array}{c}\text { Calories } \\
(\mathrm{kcal} / 100 \mathrm{~g})\end{array}$ \\
\hline \multirow{3}{*}{ F0 } & 1 & $0.57 \pm 0.01^{\mathrm{aA}}$ & $7.98 \pm 0.13^{\mathrm{aA}}$ & $2.00 \pm 0.00^{\mathrm{aA}}$ & $66.42 \pm 0.10^{\mathrm{aA}}$ & $23.04 \pm 0.25^{\mathrm{aA}}$ & $132.06 \pm 0.80^{\mathrm{aA}}$ \\
\hline & 14 & $0.63 \pm 0.01^{\mathrm{aA}}$ & $7.85 \pm 0.52^{\mathrm{aA}}$ & $1.33 \pm 0.57^{\mathrm{aAB}}$ & $67.37 \pm 0.03^{\mathrm{aA}}$ & $22.82 \pm 1.04^{\mathrm{aA}}$ & $134.66 \pm 2.95^{\mathrm{aA}}$ \\
\hline & 28 & $0.64 \pm 0.13^{\mathrm{aA}}$ & $8.01 \pm 0.47^{\mathrm{aA}}$ & $1.00 \pm 0.00^{\mathrm{aB}}$ & $68.09 \pm 0.53^{\mathrm{aA}}$ & $22.25 \pm 0.53^{\mathrm{aA}}$ & $130.06 \pm 2.12^{\mathrm{aA}}$ \\
\hline \multirow{3}{*}{ F1 } & 1 & $0.63 \pm 0.00^{\mathrm{aA}}$ & $6.81 \pm 0.56^{\mathrm{abA}}$ & $1.66 \pm 1.15^{\mathrm{aA}}$ & $68.32 \pm 0.21^{\mathrm{aA}}$ & $22.57 \pm 1.17^{\mathrm{aA}}$ & $132.50 \pm 6.31^{\mathrm{aA}}$ \\
\hline & 14 & $0.59 \pm 0.05^{\mathrm{aA}}$ & $8.43 \pm 0.07^{\mathrm{abA}}$ & $1.00 \pm 0.00^{\mathrm{aAB}}$ & $67.72 \pm 0.29^{\mathrm{aA}}$ & $22.25 \pm 0.31^{\mathrm{aA}}$ & $131.74 \pm 0.96^{\mathrm{aA}}$ \\
\hline & 28 & $0.64 \pm 0.00^{\mathrm{aA}}$ & $7.92 \pm 2.39^{\mathrm{abA}}$ & $1.00 \pm 0.0^{\mathrm{aB}}$ & $68.09 \pm 0.29^{\mathrm{aA}}$ & $23.02 \pm 2.66^{\mathrm{aA}}$ & $132.76 \pm 1.32^{\mathrm{aA}}$ \\
\hline \multirow{3}{*}{$\mathrm{F} 2$} & 1 & $0.65 \pm 0.02^{\mathrm{aA}}$ & $6.87 \pm 0.55^{\mathrm{bA}}$ & $1.33 \pm 0.57^{\mathrm{aA}}$ & $73.53 \pm 9.10^{\mathrm{aA}}$ & $22.99 \pm 0.17^{\mathrm{aA}}$ & $130.06 \pm 4.06^{\mathrm{aA}}$ \\
\hline & 14 & $0.64 \pm 0.00^{\mathrm{aA}}$ & $6.17 \pm 0.61^{\mathrm{bA}}$ & $1.66 \pm 0.57^{\mathrm{aAB}}$ & $68.07 \pm 1.24^{\mathrm{aA}}$ & $23.46 \pm 2.11^{\mathrm{aA}}$ & $132.76 \pm 5.05^{\mathrm{aA}}$ \\
\hline & 28 & $0.62 \pm 0.02^{\mathrm{aA}}$ & $7.52 \pm 0.13^{\mathrm{bA}}$ & $1.00 \pm 0.00^{\mathrm{aB}}$ & $67.60 \pm 0.44^{\mathrm{aA}}$ & $23.26 \pm 0.49^{\mathrm{aA}}$ & $132.12 \pm 1.70^{\mathrm{aA}}$ \\
\hline
\end{tabular}

*Abbreviations are: F0, guava-flavored petit-suisse kefir cheese (control treatment); F1, guava-flavored petit-suisse kefir cheese with 3\% of inulin and F2, guava-flavored petit-suisse kefir cheese with $6 \%$ of inulin. **Averages $(n=3)$ followed by the same letter (uppercase) and (lowercase) in the column do not differ during the storage time and the formulations, respectively, according to Tukey Test ( $p>0.05)$. Source: Authors.

Regarding protein content, was observed that there was a significant difference ( $<<0.05)$ among the formulations; F0 had a higher content and F2 had lower values. Relating protein content with the amount of inulin added to petit-suisse cheese, 
it was noticed a reduction in the protein amount, as the concentration of inulin increased in the formulations. This reduction may be due to the activity of proteinase in yeast in petit-suisse kefir cheese. Lactic acid bacteria are weakly proteolytic but possess a very comprehensive range of proteinases/peptidases capable of hydrolyzing casein-derived peptides to small peptides and amino acids. When used as starters, Lactococcus spp., Lactobacillus spp., and St. thermophilus have extensive activity in cheese, particularly in the production of short peptides and free amino acids (Hayaloglu, Guven, Fox, Hannon \& McSweeney, 2004; Gonku \& Alpkent, 2005). In addition to softening the cheese body, proteolysis influences the development of cheese flavor via the formation of amino acids and peptides, which make a direct contribution to the flavor (Fox, McSweeney \& Singh, 1995).

Despite the occurrence of such reduction in protein content in the formulations (Table 3), was did not observe any significant difference during the storage time $(\mathrm{p}>0.05)$. Protein contents varied between $6.17 \%$ and $8.43 \%$. These values are within the permitted by law (Brasil, 2000) which sets forth a minimum of $6.00 \%$ of lactic proteins in petit-suisse cheese.

Although inulin is used as a replacement to fat in several products, this study showed that it did not influence the formulations ( $p>0.05$ ), having its content reduced during storage ( $p>0.05$ ) for all formulations (Table 3). This reduction is probably related to the influence of yeast on this product, since some strains of Kluyveromyces and Debaryomyces can produce lipolytic enzymes and process milk fat (Fleet, 1990).

Regardless of lipolytic activity in products such as milk, yogurt, and butter are not highly desired, a certain level of lipolysis is desirable in some types of cheese in terms of forming the aroma and structure (Yerlikaya, 2019). The formation of volatile free fatty acids due to the lipolytic activity of microorganisms during ripening may be the cause of the decreased fat content in white pickled cheese (Gonku \& Alpkent, 2005).

The amounts of fat varied from 1 to $2 \%$, which refers only to the content related to UHT whole milk, because the product was not added with fat. Prudencio et al. (2008) observed higher values, with a variation from $4.30 \%$ to $4.60 \%$, and Cardarelli et al. (2008) with values ranging between 3.48\% and 3.83\%. Pereira et al. (2016) observed higher values ranging from 4.42 to $4.16 \%$.

Regarding the instrumental color analysis, it was observed that the cheeses were different from the three parameters we assessed $\left(L^{*}, a^{*}, b^{*}\right)$. $L^{*}$ was higher for $F 2(p<0.05)$, thus being the sample with the highest luminosity, probably because it has more inulin in its composition (6\%). As for storage time, we may highlight that such luminosity increased in times 14 and 28 days of storage $(\mathrm{p}<0.05)$ for all formulations. Values of $\mathrm{L}^{*}$ varied from 80.21 to 85.25 , near 100 , tending to white (Table 4). 
Table 4 - Analysis of instrumental color and viscosity of guava-flavored petit-suisse kefir cheese with different concentrations of inulin, stored at $4 \pm 1^{\circ} \mathrm{C}$.

\begin{tabular}{|c|c|c|c|c|c|}
\hline \multirow{2}{*}{ Formulations $* *$} & \multirow{2}{*}{$\begin{array}{c}\text { Storage } \\
\text { time } \\
\text { (Days) }\end{array}$} & \multicolumn{4}{|c|}{ Average Values \pm Standard Deviation $* * *$} \\
\hline & & $\mathrm{L}^{*}$ & $a^{*}$ & $b^{*}$ & Viscosity (cP) \\
\hline \multirow{3}{*}{ F0 } & 1 & $81.52 \pm 0.19^{\mathrm{bB}}$ & $7.35 \pm 0.23^{\mathrm{aA}}$ & $11.66 \pm 0.32^{\mathrm{aC}}$ & $1520.30 \pm 4.04^{\mathrm{bA}}$ \\
\hline & 14 & $83.91 \pm 0.73^{\mathrm{bA}}$ & $6.82 \pm 0.10^{\mathrm{aB}}$ & $12.54 \pm 0.33^{\mathrm{aB}}$ & - \\
\hline & 28 & $84.46 \pm 0.91^{\mathrm{aA}}$ & $5.84 \pm 0.07^{\mathrm{aC}}$ & $13.33 \pm 0.09^{\mathrm{aA}}$ & $1516.58 \pm 3.21^{\mathrm{bB}}$ \\
\hline \multirow{3}{*}{$\mathrm{F} 1$} & 1 & $80.21 \pm 0.54^{\mathrm{cB}}$ & $7.10 \pm 0.15^{\mathrm{aA}}$ & $11.64 \pm 0.26^{\mathrm{aC}}$ & $1521.94 \pm 4.61^{\mathrm{abA}}$ \\
\hline & 14 & $84.39 \pm 0.29^{\mathrm{abA}}$ & $6.69 \pm 0.04^{\mathrm{aB}}$ & $12.37 \pm 0.25^{\mathrm{aB}}$ & - \\
\hline & 28 & $85.06 \pm 0.78^{\mathrm{aA}}$ & $5.69 \pm 0.05^{\mathrm{aC}}$ & $12.76 \pm 0.14^{\mathrm{aA}}$ & $1516.10 \pm 3.12^{\mathrm{abB}}$ \\
\hline \multirow{3}{*}{$\mathrm{F} 2$} & 1 & $83.19 \pm 0.17^{\mathrm{aB}}$ & $7.10 \pm 0.15^{\mathrm{aA}}$ & $11.64 \pm 0.26^{\mathrm{aC}}$ & $1527.82 \pm 1.80^{\mathrm{aA}}$ \\
\hline & 14 & $85.15 \pm 0.46^{\mathrm{aA}}$ & $6.78 \pm 0.51^{\mathrm{aB}}$ & $12.48 \pm 0.48^{\mathrm{aB}}$ & - \\
\hline & 28 & $85.26 \pm 0.48^{\mathrm{aA}}$ & $5.48 \pm 0.07^{\mathrm{aC}}$ & $12.69 \pm 0.10^{\mathrm{aA}}$ & $1526.94 \pm 2.49^{\mathrm{aB}}$ \\
\hline
\end{tabular}

**Abbreviations are: F0, guava-flavored petit-suisse kefir cheese (control treatment); F1, guava-flavored petit-suisse kefir cheese with $3 \%$ of inulin and F2, guava-flavored petit-suisse kefir cheese with $6 \%$ of inulin. ***Averages $(n=3)$ followed by the same letter (uppercase) and (lowercase) in the column do not differ during the storage time and the formulations, respectively, according to Tukey Test ( $>0.05$ ). $\mathrm{L}^{*}$, luminosity; $\mathrm{a}^{*}$ and $\mathrm{b}^{*}$ chromaticity coordinates. Source: Authors.

The coordinates of chromaticity a* were positive towards red, with average values within the range of 5.48 to 7.35. It was observed that, for $\mathrm{a}^{*}$, adding inulin did not affect the formulations statistically $(\mathrm{p}>0.05)$. However, was verified that such parameter was reduced in all formulations during the final storage time $(\mathrm{p}<0.05)$, i.e., the longer the product remained in storage, the more reduced red became.

Values of chromaticity $b^{*}$ were above zero, with average values varying between 11.64 and 12.76 . As for $b^{*}$, was investigated that adding inulin did not affect the formulations statistically $(\mathrm{p}>0.05)$. However, it was determined that parameter $b^{*}$ increased in all formulations during the storage times $(\mathrm{p}<0.05)$, i.e., the longer the product remained in storage, the stronger the yellow color became.

This loss in red and gain in yellow (Table 4) may be related to pigments present in the formulations of guava-flavored petit-suisse kefir cheese. In addition to lycopene, other carotenoids found in products based on guava are: $\beta$-carotene, $\gamma$ carotene, $\beta$-cryptoxanthin, rubyxanthin, cryptoflavin, lutein, and neochrome (Thaipong, Boonprakob, Crosby, CisnerosZevallos, \& Byrne, 2006).

The color of the food surface is the first quality parameter evaluated by consumers, and it is critical for product acceptance. Food appearance determined mostly by surface color is the first sensation that the consumer perceives and uses as a tool to either accept or reject a food (Leon, Mery, Pedreschi \& Leon, 2006; Pathare, Opara \& Al-Said, 2013).

Regarding viscosity vales, we noticed that there was a statistical difference between formulations ( $p<0.05)$; F2 had the highest viscosity values when compared to F0. Leahu, Ghinea e Damian (2018) also observed that formulations with added fibers (inulin 3 and 6\% and psyllium 3 and 6\%) in blueberry ice cream showed higher viscosity values (600.66 to 10559 $\left.\mathrm{mPa}^{*} \mathrm{~s}\right)$ compared to the control $(600 \mathrm{mPa} * \mathrm{~s})$. However, Tiwari, Sharma, Kumar e Kaur (2015) observed that the viscosity of ice cream mixes decreased with increasing incorporation of inulin $(0,2,4$, and $6 \%)$, suggesting that any interaction between inulin microcrystals was less than that between fat globules.

Inulin can act as a texture modifier in dietary products and, in low concentrations, varying from $5 \%$ to $10 \%$, inulin 
grants a significant increase in viscosity, whereas in concentrations from $40 \%$ to $45 \%$, it makes a gel (Murphy, 2001). The amounts of inulin added (3\% and 6\%) caused modifications to the viscosity of petit-suisse kefir cheese.

It was also pointed out that there was a significant reduction $(\mathrm{p}<0.05)$ in viscosity values for all formulations, during storage time (Table 4). Such reduction in viscosity may be related to the reduction in fat content in the formulations, during the final storage time (Table 3).

\subsection{Microbiological analyses}

Adding $3 \%$ and $6 \%$ of inulin significantly decreased the population of lactic acid bacteria $(\mathrm{p}<0.05)$ in guava-flavored petit-suisse cheese, when compared to the control treatment (F0) (Table 5). It was also verified that there was a significant reduction in the number of lactic acid bacteria for all formulations during the storage times $(\mathrm{p}<0.05)$.

Table 5 - Microbiological composition of guava-flavored petit-suisse kefir cheese with different concentrations of inulin, stored at $4 \pm 1{ }^{\circ} \mathrm{C}$.

\begin{tabular}{|c|c|c|c|c|}
\hline Formulations* & $\begin{array}{c}\text { Storage } \\
\text { time (Days) }\end{array}$ & $\begin{array}{c}\text { Lactic Acid } \\
\left(\log \text { CFU.g }{ }^{-1}\right)\end{array}$ & $\begin{array}{c}\text { Acetic Acid } \\
(\log \text { CFU.g-1) }\end{array}$ & $\begin{array}{c}\text { Yeast } \\
\left(\log \text { CFU.g }{ }^{-1}\right)\end{array}$ \\
\hline \multirow{3}{*}{ F0 } & 1 & $14.69 \pm 0.42^{\mathrm{aA}}$ & $7.41 \pm 0.03^{\mathrm{aA}}$ & $11.90 \pm 0.03^{\mathrm{aA}}$ \\
\hline & 14 & $12.82 \pm 0.18^{\mathrm{aB}}$ & $6.42 \pm 0.01^{\mathrm{abB}}$ & $10.66 \pm 0.08^{\mathrm{aB}}$ \\
\hline & 28 & $12.28 \pm 0.60^{\mathrm{aB}}$ & $5.69 \pm 0.05^{\mathrm{bC}}$ & $8.87 \pm 0.06^{\mathrm{aC}}$ \\
\hline \multirow{3}{*}{$\mathrm{F} 1$} & 1 & $13.37 \pm 0.02^{\mathrm{bA}}$ & $7.40 \pm 0.02^{\mathrm{aA}}$ & $11.87 \pm 0.08^{\mathrm{aA}}$ \\
\hline & 14 & $12.78 \pm 0.14^{\mathrm{aB}}$ & $6.37 \pm 0.05^{\mathrm{abB}}$ & $10.62 \pm 0.09^{\mathrm{aB}}$ \\
\hline & 28 & $11.59 \pm 0.02^{\mathrm{bC}}$ & $5.63 \pm 0.10^{\mathrm{bC}}$ & $8.79 \pm 0.06^{\mathrm{aC}}$ \\
\hline \multirow{3}{*}{$\mathrm{F} 2$} & 1 & $13.37 \pm 0.02^{\mathrm{bA}}$ & $7.40 \pm 0.01^{\mathrm{aA}}$ & $11.82 \pm 0.09^{\mathrm{aA}}$ \\
\hline & 14 & $12.85 \pm 0.10^{\mathrm{aA}}$ & $6.33 \pm 0.05^{\mathrm{abB}}$ & $10.60 \pm 0.02^{\mathrm{aA}}$ \\
\hline & 28 & $11.57 \pm 0.03^{\mathrm{bB}}$ & $5.56 \pm 0.02^{\mathrm{bC}}$ & $8.87 \pm 0.05^{\mathrm{aC}}$ \\
\hline
\end{tabular}

*Abbreviations are: F0, guava-flavored petit-suisse kefir cheese (control treatment); F1, guava-flavored petit-suisse kefir cheese with $3 \%$ of inulin and F2, guava-flavored petit-suisse kefir cheese with $6 \%$ of inulin. **Averages $(\mathrm{n}=3)$ followed by the same letter (uppercase) and (lowercase) in the column do not differ during the storage time and the formulations, respectively, according to Tukey Test ( $>0.05$ ). Source: Authors.

Regarding acetic acid bacteria and yeast, no statistical difference was observed due to the addition of inulin to the formulations $(p>0.05)$. However, a decrease in acetic acid bacteria was noted during the storage time $(p<0.05)$ for each formulation. One of the possible causes for such a decrease in microorganisms of petit-suisse kefir cheese may be related to $\mathrm{pH}$ values in this product (Table 2). A pH content implies the metabolic activity of bacteria, which can benefit a given group and harm another.

A reduction in the number of microorganisms during the storage time of probiotic cheeses was investigated by Cardarelli et al. (2008), noting that, despite the decrease in probiotic populations (Lactobacillus acidophilus and Bifidobacterium animalis subsp. lactis) in symbiotic petit-suisse cheese during storage time under refrigeration ( 1 and 28 days) at $4{ }^{\circ} \mathrm{C}$, both numbers always remained above 6 and $7 \log \mathrm{CFU} \cdot \mathrm{g}^{-1}$, respectively, for the product's functional purposes. As for Streptococcus thermophiles, they observed populations larger than $9 \log$ CFU.g ${ }^{-1}$.

A lot of researches have been done on the effect of adding inulin upon the growth of microorganisms in cheeses and lacteous desserts. Modzelewska-Kapituła et al. (2007) observed that adding inulin HPX influenced the number of potentially probiotic bacteria in unripe white cheese. The authors pointed out that, in cheese samples with inulin, the average number of 
Lactobacillus plantarum was greater than in cheese samples without inulin, during all the storage time (2, 20, and 45 days). The numbers varied from $1.9 \times 10^{7}$ to $4.6 \times 10^{7}$ CFU.g ${ }^{-1}$, which complies with the criteria established for probiotic foods. A study by Melo et al. (2018) in analyzing Quark cheese with the addition of agave inulin observed a significant influence on the lactobacilli count during 14 days of storage, however, the counts remained high.

Viability during storage is the result of different relevant variables that include the initial number of microorganisms, composition of the carrier medium, water activity, storage temperature, oxygen content, and relative humidity in the packaging (Chávez \& Ledeboer, 2007; Teijeiro, Pérez, De Antoni \& Golowczyc, 2018).

The number of lactic acid bacteria ranged from 11.57 to $14.68 \mathrm{log}$ CFU.g ${ }^{-1}$; as for acetic acid bacteria from 5.56 to $7.41 \log$ CFU.g ${ }^{-1}$ and yeast from 8.79 to $11.90 \log$ CFU.g ${ }^{-1}$ (Table 5). For data converted into CFU.g ${ }^{-1}$, the numbers ranged from $10^{11}$ to $10^{14}$ for lactic acid bacteria; from $10^{5}$ to $10^{7}$ for acetic acid bacteria, and from $10^{8}$ to $10^{11}$ for yeast, which are amounts considered for functional effects.

According to the literature, the minimum dosage of probiotic cells per day for any beneficial effect on the consumer is considered probiotic $10^{8}-10^{9}$ probiotic CFU.mL ${ }^{-1}$ or CFU.g ${ }^{-1}$, which corresponds to an intake of $100 \mathrm{~g}$ of a product containing $10^{6}-10^{7}$ CFU.mL ${ }^{-1}$ or CFU.g ${ }^{-1}$ per day (Lorens-Hattingh \& Viljoen, 2001; Lee \& Salminem, 2008; Araújo, Pires, Pinto, Jan, \& Carvalho, 2012; Alves et al., 2015).

In Brazil, the claim of functional or health property must be proposed by the food manufacturer and will be evaluated, case by case, based on the definitions and principles established in Resolution n. 19/1999 (Brasil, 1999). To prove the safety and efficacy of the product, at least the following information must be presented: Characterization of the micro-organism; Antimicrobial resistance profile and information on the genetic basis of antimicrobial resistance; Determination of hemolytic activity for species with hemolytic potential; Studies available in the literature that describe adverse effects observed with the strain in question and demonstration of efficacy (Brasil, 2016).

According to Resolution 241/2018, proof of benefit for probiotics requires demonstration of survival to conditions of the human digestive tract and evidence of the effect on humans obtained through studies (Brasil, 2018). Thus, further studies (clinical trials) with guava-flavored petit-suisse kefir cheese with inulin are necessary to claim functional properties in the product. Furthermore, the legislation indicates that studies in animal models, ex vivo or in vitro, can be displayed as support information for the proposed relationship, but not enough to substantiate any type of claim (Brasil, 2016).

There were no coliforms or Salmonella in the different formulations of guava-flavored petit-suisse kefir cheese with inulin, in any storage time. The results are within the standards provided by the Brazilian law (Brasil, 2019) for highly moist cheese (>55\%), which sets forth amounts of Escherichia coli within $10^{3} \mathrm{MPN}_{\mathrm{g}}{ }^{-1}$ and absence of Salmonella in $25 \mathrm{~g}$ of product. The microbiological results showed good hygiene-sanitary conditions of the raw material and the handling during the manufacture. These data corroborate those by Bermudez-Beltrán et al. (2020) and Saito et al. (2019) when evaluating gooseberry petit suisse cheese and petit suisse cheese made with jabuticaba peel, respectively.

\subsection{Sensory analysis}

\subsubsection{Consumer's profile}

Sensory analysis was performed with 120 consumers, $66.1 \%$ women and $33.9 \%$ men, aged between 18 and 50 years, the majority being 18 to 30 years old (90.9\%). Regarding the level of education (complete or in progress), more than half of the evaluators (55.9\%) undergraduate, $31.4 \%$ high school, and $12.7 \%$ postgraduate studies.

Regarding the frequency of consumption of petit-suisse cheese, among the study participants, $28.46 \%$ said they consume it every month, followed by those who consume it 1 to 3 times a week (21.54\%). Some tasters reported consuming this type of cheese every fifteen days $(14.61 \%)$, just as $(18.46 \%)$ stated that they consume it every day and others that they 
rarely consume it $(16.93 \%)$.

\subsubsection{Acceptance test and purchase intention}

The storage time and adding inulin did not influence the acceptance towards guava-flavored petit-suisse kefir cheese as to appearance, aroma, and texture (Table 6).

Table 6 - Average grades for sense attributes (overall impression, appearance, aroma, texture, flavor) and purchase intention of guava-flavored petit-suisse kefir cheese with different concentrations of inulin, stored at $4 \pm 1{ }^{\circ} \mathrm{C}$.

\begin{tabular}{|c|c|c|c|c|c|c|c|}
\hline \multirow{2}{*}{$\begin{array}{l}\text { Formul } \\
\text { ations* }\end{array}$} & \multirow{2}{*}{$\begin{array}{c}\text { Storage } \\
\text { Time } \\
\text { (Days) }\end{array}$} & \multicolumn{6}{|c|}{ Average Values \pm Standard Deviation $* *$} \\
\hline & & $\begin{array}{c}\text { Overall } \\
\text { Impression }\end{array}$ & Appearance & Aroma & Texture & Flavor & $\begin{array}{l}\text { Purchase } \\
\text { Intention }\end{array}$ \\
\hline \multirow{2}{*}{ F0 } & 1 & $6.86 \pm 1.38^{\mathrm{aA}}$ & $7.01 \pm 1.31^{\mathrm{aA}}$ & $6.56 \pm 1.77^{\mathrm{aA}}$ & $6.92 \pm 1.57^{\mathrm{aA}}$ & $6.40 \pm 1.95^{\mathrm{aA}}$ & $3.59 \pm 1.08^{\mathrm{aA}}$ \\
\hline & 28 & $6.93 \pm 1.71^{\mathrm{aA}}$ & $7.12 \pm 1.54^{\mathrm{aA}}$ & $6.82 \pm 1.63^{\mathrm{aA}}$ & $7.00 \pm 1.57^{\mathrm{aA}}$ & $6.58 \pm 2.01^{\mathrm{aA}}$ & $3.60 \pm 1.36^{\mathrm{aA}}$ \\
\hline \multirow{2}{*}{$\mathrm{F} 1$} & 1 & $6.50 \pm 1.90^{\mathrm{abA}}$ & $6.93 \pm 1.47^{\mathrm{aA}}$ & $6.60 \pm 1.71^{\mathrm{aA}}$ & $6.82 \pm 1.84^{\mathrm{aA}}$ & $6.25 \pm 2.13^{\mathrm{aA}}$ & $3.45 \pm 1.13^{\mathrm{aA}}$ \\
\hline & 28 & $6.56 \pm 1.80^{\mathrm{abA}}$ & $6.95 \pm 1.85^{\mathrm{aA}}$ & $6.62 \pm 1.76^{\mathrm{aA}}$ & $6.80 \pm 1.67^{\mathrm{aA}}$ & $6.20 \pm 2.00^{\mathrm{aA}}$ & $3.39 \pm 1.38^{\mathrm{aA}}$ \\
\hline \multirow{2}{*}{$\mathrm{F} 2$} & 1 & $6.21 \pm 1.67^{\mathrm{bA}}$ & $6.70 \pm 1.52^{\mathrm{aA}}$ & $6.34 \pm 1.64^{\mathrm{aA}}$ & $6.56 \pm 1.73^{\mathrm{aA}}$ & $5.75 \pm 1.87^{\mathrm{bA}}$ & $3.07 \pm 1.02^{\mathrm{bA}}$ \\
\hline & 28 & $6.27 \pm 1.63^{\mathrm{bA}}$ & $6.82 \pm 1.81^{\mathrm{aA}}$ & $6.51 \pm 1.62^{\mathrm{aA}}$ & $6.78 \pm 1.69^{\mathrm{aA}}$ & $5.59 \pm 2.00^{\mathrm{bA}}$ & $3.14 \pm 1.31^{\mathrm{bA}}$ \\
\hline
\end{tabular}

*Abbreviations are: F0, guava-flavored petit-suisse kefir cheese (control treatment); F1, guava-flavored petit-suisse kefir cheese with 3\% of inulin and F2, guava-flavored petit-suisse kefir cheese with $6 \%$ of inulin. **Averages $(n=3)$ followed by the same letter (uppercase) and (lowercase) in the column do not differ during the storage time and the formulations, respectively, according to Tukey Test ( $\mathrm{p}>0.05$ ). Source: Authors.

The scores ranged from 6.7 to 7.12 for appearance, positioned between 'Like slightly' and 'Like moderately'. As for the aroma between 6.34 and 6.82 , it corresponds to 'Like slightly'. Some tasters mentioned the characteristic aroma of petitsuisse kefir cheese as pleasant, due to the addition of guava pulp, and others as unpleasant because it resembled curd. Regarding texture, the scores varied between 6.56 and 7.00, located between 'Like slightly' and 'Like moderately'.

When it comes to flavor, the average values varied from 5.59 to 6.58 , which corresponds to 'Neither like nor dislike' and 'Like slightly'. During storage times, there were no statistical differences $(\mathrm{p}>0.05)$ for flavor. However, there was a significant difference between formulations $(\mathrm{p}<0.05)$. The formulation with the highest concentration of inulin $(\mathrm{F} 2=6 \%)$ showed the lowest flavor values when compared to F0 (0\%) and F1 (3\%). This result is probably related to the product's pH since the $\mathrm{pH}$ in F2 was lower than that of the other formulations (F0 and F2) (Table 2). Some tasters mentioned the acidic flavor of guava-flavored petit-suisse kefir cheese as a negative attribute. Substances produced by the microorganisms in this product, such as organic acids, can reduce $\mathrm{pH}$ and, thereby alter the sensory characteristics of cheese (Shah, 2000).

For overall impression, the average scores ranged from 6.21 to 6.93 , which corresponds to 'Like slightly'. The F0 formulation had the best acceptance concerning the others.

Leahu et al. (2018) observed that formulations with the highest fiber concentrations (6\% inulin and 6\% psyllium) in blueberry ice cream had higher scores in the acceptance test ( 8.7 and 8.8 , respectively), suggesting that ice cream with higher fiber proportions are well accepted.

Regarding purchase intention, the scores ranged from 3.07 to 3.59, defined 'might/might not buy' to 'would probably buy'. There was a significant difference between the formulations $(\mathrm{p}<0.05)$, where F2 had the lowest purchase intention compared to F0 and F1.

Saito et al. (2019) found no differences in the purchase intent of petit-suisse cheese formulations incorporated with 
different jabuticaba peel extract concentrations, with scores ranged from 3.3 to 3.5. However, the results for purchase intention of formulations did not differ ( $p>0.05$ ) during the storage times ( 1 and 28 days) (Table 6). Despite this, all formulations had an acceptance rate above $70 \%$ for most of the attributes evaluated during the final storage time (Table 7) as indicated by the acceptability index (AI).

Table 7 - Acceptability Index (\%) of guava-flavored petit-suisse kefir cheese with different concentrations of inulin, stored at $4 \pm 1^{\circ} \mathrm{C}$.

\begin{tabular}{|c|c|c|c|c|c|c|}
\hline \multirow[b]{2}{*}{ Formulations* } & \multirow{2}{*}{$\begin{array}{c}\text { Storage } \\
\text { Time } \\
\text { (Days) }\end{array}$} & \multicolumn{5}{|c|}{ Acceptability Index (\%) } \\
\hline & & $\begin{array}{c}\text { Overall } \\
\text { Impression }\end{array}$ & Appearance & Aroma & Texture & Flavor \\
\hline \multirow{2}{*}{ F0 } & 1 & 76.2 & 77.8 & 72.8 & 76.8 & 71.1 \\
\hline & 28 & 77.0 & 79.1 & 75.7 & 77.7 & 73.1 \\
\hline \multirow{2}{*}{$\mathrm{F} 1$} & 1 & 72.2 & 77.0 & 73.3 & 75.7 & 69.4 \\
\hline & 28 & 72.8 & 77.2 & 73.5 & 75.5 & 68.8 \\
\hline \multirow{2}{*}{$\mathrm{F} 2$} & 1 & 69.0 & 74.4 & 70.4 & 72.8 & 63.8 \\
\hline & 28 & 69.6 & 75.7 & 72.3 & 75.3 & 62.1 \\
\hline
\end{tabular}

*Abbreviations are: F0, guava-flavored petit-suisse kefir cheese (control treatment); F1, guava-flavored petit-suisse kefir cheese with $3 \%$ of inulin and F2, guava-flavored petit-suisse kefir cheese with $6 \%$ of inulin. Source: Authors.

For a product to be considered acceptable in terms of sensory properties by the evaluators, it is necessary that it obtain an Acceptability Index of at least 70\% (Dutcosky, 2013). It is observed that only the flavor attribute, in the F2 formulation, obtained an acceptance of $64 \%$. Thus, guava-flavored kefir petit-suisse cheese with inulin stored for 28 days at a temperature of $4{ }^{\circ} \mathrm{C}$ was well accepted.

\section{Conclusion}

The addition of inulin significantly altered the physicochemical characteristics of guava-flavored petit-suisse kefir cheese, except for moisture, water activity, ash, proteins, and carbohydrates. The samples had good hygiene-sanitary conditions, which was confirmed by the absence of total and thermotolerant coliforms, and a reduction in the number of lactic acid bacteria, acetic acid bacteria, and yeast was observed in the final storage time. Sensory attributes, such as flavor, overall impression, and purchase intention, were also influenced by the concentration of inulin, except for appearance, aroma, and texture.

The low levels of fructans found do not characterize the product's prebiotic claim. Despite this, the guava-flavored petit-suisse kefir cheese is likely to large-scale production, being a nutritious food with good microbiological, physicochemical and sensory quality until 28 days of storage.

Thus, it is recommended for future studies to improve the product formulation to achieve better purchase intent scores, as well as the use of clinical trials to verify the claim of functional properties in the product.

\section{Acknowledgments}

The authors are grateful to the Coordenação de Aperfeiçoamento de Pessoal de Nivel Superior (CAPES), the Fundação Cearense de Apoio ao Desenvolvimento Científico e Tecnológico (FUNCAP) (process number 23038.008847/2013- 
33), the Conselho Nacional de Desenvolvimento Científico e Tecnológico (CNPq) and the Instituto Federal de Educação, Ciência e Tecnologia do Ceará (IFCE) for financial support. They are also grateful for the scholarships granted FUNCAP (first author), $\mathrm{CNPq}$ (second and third authors), CAPES (fourth and sixth authors) CAPES/PNPD (seventh and eighth authors).

\section{References}

Association of Official Analytical Chemists - AOAC. (2007). Official Methods of Analysis of AOAC International. (18th ed.). AOAC International.

American Public Health Association - APHA. (2001). Compendium of methods for the microbiological examination of foods. (4th ed.). APHA International.

Alves, M., Peres, C. M., Hernandez-Mendonza, A., Bronze, M. S., Peres, C., Malcata, F. X. (2015). Olive paste as vehicle for delivery of potential probiotic Lactobacillus Plantarum 33. Food Research International, 75(9), 61-70. https://doi.org/10.1016/j.foodres.2015.04.048

Araújo, E. A., Pires, A. C. dos S., Pinto, M. S., Jan, G., \& Carvalho. A. F. de. (2012) Probiotics in dairy fermented products. In: E. Rigobelo (Ed.), Probiotics, (Chap 6, pp. 129-148). São Paulo: Intech Open. https://doi.org/10.5772/51939

Bermudez-Beltrán, K. A., Marzal-Bolaño, J. K., Olivera-Martínez, A. B., \& Espitia, P. J. P. (2020). Cape gooseberry Petit Suisse Cheese incorporated with moringa leaf powder and gelatin. LWT-Food Science and Technology, 123(7), 109101. https://doi.org/10.1016/j.lwt.2020.109101

Brasil (2000). Ministério da Agricultura, Pecuária e do Abastecimento. Instrução normativa $n^{\circ} 53$, de 29 de dezembro de 2000 . Dispõe sobre o Regulamento Técnico de Identidade e Qualidade de Queijo Petit-Suisse. Diário Oficial da União. Brasília, DF. n. 3, Seção 1, p. 3-5.

Brasil (1999). Ministério da Saúde. Agência Nacional de Vigilância Sanitária. Resolução no 19 de 30 de abril de 1999. Aprova o Regulamento Técnico que estabelece as diretrizes básicas para análise e comprovação de propriedades funcionais e ou de saúde alegadas em rotulagem de alimentos. Diário Oficial da União. Brasília, DF. n. 236-E, Seção 1, p. 32.

Brasil (2013). Ministério da Saúde. Agência Nacional de Vigilância Sanitária. Resolução no 466 do Conselho Nacional de Saúde, de 12 de dezembro de 2012. Aprova as diretrizes e normas regulamentadoras de pesquisas envolvendo seres humanos. Diário Oficial da União, Brasília, DF. $\mathrm{n}^{\circ} 12$, Seção 1 , $\mathrm{p}$. 59 .

Brasil (2016). Ministério da Saúde. Agência Nacional de Vigilância Sanitária. Alimentos com alegações de propriedades funcionais e ou de saúde. Atualizado. 22 de dezembro de 2016. https://www.gov.br/anvisa/pt-br/assuntos/noticias-anvisa/2016/anvisa-atualiza-lista-de-alegacoes-de-propriedades-funcionais-e-desaude.

Brasil (2018). Ministério da Saúde. Agência Nacional de Vigilância Sanitária. Resolução RDC no 241, de 26 de julho de 2018. Requisitos para comprovação da segurança e dos benefícios à saúde dos probióticos para uso em alimentos. Diário Oficial da União. Brasília, DF. Edição 144 , Seção 1, p. 97.

Brasil (2019). Ministério da Saúde. Resolução RDC $n^{o}$ 331, de 23 de dezembro de 2019. Dispõe sobre os padrões microbiológicos de alimentos e sua aplicação. Diário Oficial da União. Brasília, DF. n. 249, Seção 1, p. 96-97.

Buriti, F. C. A., Rocha, J. S., \& Saad, S. M. I. (2005). Incorporation of Lactobacillus acidophilus in Minas fresh cheese and its implications for textural and sensorial properties during storage. International Dairy Journal, 15(12), 1279-1288. https://doi.org/10.1016/j.idairyj.2004.12.011

Cardarelli, H. R., Buriti, F. C. A., Castro, I. A., \& Saad, S. M. I. (2008). Inulin and oligofructose improve sensory quality and increase the probiotic viable count in potentially synbiotic petit-suisse cheese. LWT - Food Science and Technology, 41(6), 1037-1046. https://doi.org/10.1016/j.1wt.2007.07.001

Cervo, A. L., Bervian, P. A., \& Silva, R. (2007). Metodologia científica. (6a ed.), Prentice Hall.

Charalampopoulos, D., \& Rastall, R. A. (2012). Prebiotics in foods. Current Opinion in Biotechnology, 23(2), 187-191. https://doi.org/10.1016/j.copbio.2011.12.028

Chávez, B. E., \& Ledeboer, A. M. (2007). Drying of probiotics: Optimization of formulation and process to enhance storage survival. Drying Technology. 25(7-8), 1193- 1201. https://doi.org/10.1080/07373930701438576

Colantonio, A. G., Werner, S. L., \& Brown, M. (2019). The effects of prebiotics and substances with prebiotic properties on metabolic and inflammatory biomarkers in individuals with type 2 diabetes mellitus: A systematic review. Journal of the Academy of Nutrition and Dietetics. 120(4), 587-607. https://doi.org/10.1016/j.jand.2018.12.013

Cruz-Guerrero, A., Hernández-Sánchez, H., Rodríguez-Serrano, G., Gómez-Ruiz, L., García-Garibaya, M., \& Figueroa-González, I. (2014). Commercial probiotic bacteria and prebiotic carbohydrates: A fundamental study on prebiotics uptake, antimicrobials production and inhibition of pathogens. Journal of the Science Food and Agriculture, 94(11), 2246-2252. https://doi.org/10.1002/jsfa.6549

Dave, R. I., \& Shah, N. P. (1996). Evaluation of media for selective enumeration of Streptococcus thermophillus, Lactobacillus delbrueckii subsp. bulgaricus, Lactobacillus acidophilus and bifidobacteria. Journal of Dairy Science, 79(9), 1529-1536. https://doi.org/10.3168/jds.S0022-0302(96)76513-X

Delzenne, N. M., Olivares, M., Neyrinck, A. M., Beaumont, M., Kjølbæk, L., Larsen, T. M., Benítez-Páez, A., Romaní-Pérez, M., Garcia-Campayo, V., Bosscher, D., Sanz, Y., \& Kamp, J.-W. van der. (2019). Nutritional interest of dietary fiber and prebiotics in obesity: Lessons from the MyNewGut consortium. Clinical Nutrition, 39(2), 414-424. https://doi.org/10.1016/j.clnu.2019.03.002

Deolindo, C. T. P., Monteiro, P. I., Santos, J. S., Cruz, A. G., Silva, M. C., \& Granato, D. (2019). Phenolic-rich Petit Suisse cheese manufactured with organic Bordeaux grape juice, skin, and seed extract: Technological, sensory, and functional properties. LWT - Food Science and Technology, 115, 1-7. https://doi.org/10.1016/j.lwt.2019.108493 
Dutcosky, S. D. (2013). Análise sensorial de alimentos. 4. ed. Champagnat, 531 p.

Ertekin, B., \& Guzel-Seydim, Z. B. (2010). Effect of fat replacers on kefir quality. Journal of the Science of Food and Agriculture, 90(4), 543-548. https://doi.org/10.1002/jsfa.3855

Esmerino, E. A., Paixão, J. A., Cruz, A. G., Garitta, L., Hough, G., \& Bolini, H. M. A. (2015). Survival analysis: A consumer-friendly method to estimate the optimum sucrose level in probiotic Petit Suisse. Journal of Dairy Science, 98(11), 7544-7551. https://doi.org/10.3168/jds.2015-9651

Farias, D. P., Araujo, F. F., Neri-Numa, I. A., \& Pastore, G. M. (2019). Prebiotics: Trends in food, health and technological applications. Trends in Food Science \& Technology, 93(11), 23-35. https://doi.org/10.1016/j.tifs.2019.09.004

Farnworth, E. R., \& Mainville, I. (2008). Kefir - A fermented milk product. In: E. R. Farnworth (Ed.) Handbook of Fermented Functional Foods. (2nd. ed. Chap. 4, 89-127pp) CRC Press Taylor \& Francis Group, Boca Raton, FL; London, UK; and New York, NY.

Farnworth, E. R. (2005). Kefir - a complex probiotic. Food Science \& Technology Bulletin Functional Foods, 2(1), 1-17. https://doi.org/10.1616/14762137.13938

Fleet, G. H. (1990). Yeasts in dairy products. Journal of Applied Bacteriology, 68(3), 199-211. https://doi.org/10.1111/j.1365-2672.1990.tb02566.x

Flores, G., Wu, S.-B., Negrin, A., \& Kennelly, E. J. (2015). Chemical composition and antioxidant activity of seven cultivars of guava (Psidium guajava) fruits. Food Chemistry, 170(5), 327-335. https://doi.org/10.1016/j.foodchem.2014.08.076

Forato, L. A., de Britto, D., de Rizzo, J. S., Gastaldi, T. A., \& Assis, O. B. G. (2015). Effect of cashew gum-carboxymethylcellulose edible coatings in extending the shelf-life of fresh and cut guavas. Food Packaging and Shelf Life, 5(3), 68-74. https://doi.org/10.1016/j.fpsl.2015.06.001

Fox, P. F., McSweeney, P. L. H., \& Singh, T. K. (1995). Methods for assessing proteolysis in cheese during maturation. In: Malin, E. L. \& Tunick, M. H. (Eds) Chemistry of structure-function relationships in cheese. Advances in Experimental Medicine and Biology (v. 367; pp161-194). Springer Science+Business Media: New York. https://doi.org/10.1007/978-1-4615-1913-3

Gibson, G. R., Hutkins, R., Sanders, M. E., Prescott, S. L., Reimer, R. A., Salminen, S. J., Scott, K., Stanton, C., Swanson, K. S., Cani, P. D., Verbeke, K., \& Reid, G. (2017). The International Scientific Association for Probiotics and Prebiotics (ISAPP) consensus statement on the definition and scope of prebiotics. Nature Reviews Gastroenterology \& Hepatology, 14(8), 491-502. https://doi.org/10.1038/nrgastro.2017.75

Gonku, A., \& Alpkent, Z. (2005). Sensory and chemical properties of white pickled cheese produced using kefir, yoghurt or a commercial cheese culture as a starter. International Dairy Journal, 15(6-9), 771-776. https://doi.org/10.1016/j.idairyj.2004.10.008

Hayaloglu, A., Guven, M., Fox, P. F., Hannon, J. A., \& McSweeney, P. L. H. (2004). Proteolysis in Turkish White-brined cheese made with defined strains of Lactococcus. International Dairy Journal, 14(7), 599-610. https://doi.org/10.1016/j.idairyj.2003.12.008

Hossain, M. I., Sadekuzzaman, M., \& Ha, S.-D. (2017). Probiotics as potential alternative biocontrol agents in the agriculture and food industries: A review. Food Research International, 100(1), 63-73. https://doi.org/10.1016/j.foodres.2017.07.077

Irigoyen, A., Arana, I., Castiella, M., Torre, P., \& Ibáñez, F. C. (2005). Microbiological, physicochemical, and sensory characteristics of kefir during storage. Food Chemistry, 90(4), 613-620. https://doi.org/10.1016/j.foodchem.2004.04.021

International Organization for Standardization. International Dairy Federation. (2004). Standard Method (ISO 6611:2004 [IDF 94:2004]). Milk and milk products. Enumeration of colony-forming units of yeasts and/or moulds. Colony-count technique at 25 degrees $C$.

Karimi, R., Azizi, M. H., Ghasemlou, M., \& Vaziri, M. (2015). Application of inulin in cheese as prebiotic, fat replacer and texturizer: A review. Carbohydrate Polymers, 119(4), 85-100. https://doi.org/10.1016/j.carbpol.2014.11.029

Khaneghah, A. M., Abhari, K., Eş, I., Soares, M. B., Oliveira, R. B. A., Hosseini, H., Rezaei, M., Balthazar, C. F., Silva, R., Cruz, A. G., Ranadheera, C. S., \& Sant'Ana, A. S. (2019) Interactions between probiotics and pathogenic microorganisms in hosts and foods: A review. Trends in Food Science \& Technology, 95(11), 205-218. https://doi.org/10.1016/j.tifs.2019.11.022

Kristo, E., Biliaderis, C. G., \& Tzanetakis, N. (2003). Modelling of the acidification process and rheological properties of milk fermented with a yogurt starter culture using response surface methodology. Food Chemistry, 83(3), 437-446. https://doi.org/10.1016/S0308-8146(03)00126-2

Ku, S., Yang, S., Lee, H. H., Choe, D., Johnston, T. V., Ji, G. E., \& Park, M. S. (2020). Biosafety assessment of Bifidobacterium animalis subsp. lactis AD011 used for human consumption as a probiotic microorganism. Food Control, 117(11), 1-43. https://doi.org/10.1016/j.foodcont.2019.106985

Leahu, A., Ghinea, C., \& Damian, C. (2018). The influence of inulin and psyllium addition to ice-cream and its effects on the sensorial properties. Food and Environment Safety, 17(4), 363-371.

Lee Y. K., \& Salminen, S. (2008). Handbook of probiotics and prebiotics. (2nd Edition) John Wiley \& Sons, Hoboken. https://doi.org/10.1002/9780470432624

Leon, K., Mery, D., Pedreschi, F., \& Leon, J. (2006). Color measurement in L* a* b* units from RGB digital images. Food Research International, 39(10), 1084-1091. https://doi.org/10.1016/j.foodres.2006.03.006

Lopitz-Otsoa, F., Rementeria, A., Elguezabal, N., \& Garaizar, J. (2006). Kefir: A symbiotic yeasts-bacteria community with alleged healthy capabilities. Revista Iberoamericana de Micología, 23(2), 67-74. https://doi.org/10.1016/s1130-1406(06)70016-x

Lourens-Hattingh, A., \& Viljoen, B. C. (2001). Growth and survival of a probiotic yeast in dairy products. Food Research International, 34(9), 791-796. https://doi.org/10.1016/S0963-9969(01)00085-0 
Mano, M. C. R., Neri-Numa, I. A., Silva, J. B. da, Paulino, B. N., Pessoa, M. G., \& Pastore, G. M. (2017). Oligosaccharide biotechnology: An approach of prebiotic revolution on the industry. Applied Microbiology and Biotechnology, 102(1), 17-37. https://doi.org/10.1007/s00253-017-8564-2

Meilgaard, M. C., Carr, B. T., \& Civille, G. V. (2015). Sensory evaluation techniques. (5th ed.). CRC Press, Boca Raton, p.630

Melo, D. R., Silva, P. H. T., Rigoto, R. P., Sottoriva, H. M., Cintra, F. F., Trento, J. P., Castro, A. L. de, \& Alves, G. (2018). Quark cheese produced with kefir and agave inulin. Arquivo de Ciências Veterinárias de Zoologia da UNIPAR, 21(3), 87-92. https://doi.org/10.25110/arqvet.v21i3.7337

Meyer, D., Bayarri, S., Tárrega, A., \& Costell, E. (2011). Inulin as texture modifier in dairy products. Food Hydrocolloids, 25(8), 1881-1890. https://doi.org/10.1016/j.foodhyd.2011.04.012

Modzelewska-Kapituła, M., Kłębukowska, L., \& Kornacki, K. (2007). Influence of inulin and potentially probiotic Lactobacillus plantarum strain on microbiological quality and sensory properties of soft cheese. Polish Journal of Food and Nutrition Sciences, 57(2), $143-146$.

Mohanty, D., Misra, S., Mohapatra, S., \& Sahu, P. S. (2018). Prebiotics and synbiotics: Recent concepts in nutrition. Food Bioscience, 26(6), 152-160. https://doi.org/10.1016/j.fbio.2018.10.008

Murphy, O. (2001). Non-polyol low-digestible carbohydrates: food applications and functional benefits. British Journal of Nutrition, 85(suppl.1), S47-S53. DOI: https://doi.org/10.1079/bjn2000261

Olveira, G., \& González-Molero, I. (2016). Actualización de probióticos, prebióticos y simbióticos en nutrición clínica. Endocrinología y Nutrición, 63(9), 482-494. https://doi.org/10.1016/j.endonu.2016.07.006

Ötles, S., \& Cagindi, Ö. (2003). Kefir: A probiotic dairy-composition, nutritional and therapeutic aspects. Pakistan Journal of Nutrition, 2 (2), 54-59.

Pereira, A. S., Shitsuka, D. M., Parreira, F. J., \& Shitsuka, R. (2018). Metodologia da pesquisa científica. UFSM. https://repositorio.ufsm.br/bitstream/handle/1/15824/Lic_Computacao_MetodologiaPesquisaCientifica.pdf?sequence=1

Pereira, E. P. R., Faria, J. A. F., Cavalcanti, R. N., Garcia, R. K. A., Silva, R., Esmerino, E. A., Cappato, L. P., Arellano, D. B., Raices, R. S. L., Silva, M. C., Padilha, M. C., Meireles, M. A., Bolini, H. M. A., \& Cruz, A. G. (2016). Oxidative stress in probiotic Petit Suisse: Is the jabuticaba skin extract a potential option? Food Research International, 81(3), 149-156. https://doi.org/10.1016/j.foodres.2015.12.034

Phatare, P. B., Opara, U. L., \& Al-Said, F. A-J. (2013). Colour measurement and analysis in fresh and processed foods: A review. Food and Bioprocess Technology, 6(1), 36-60. https://doi.org/10.1007/s11947-012-0867-9

Prudencio, I. D., Prudêncio, E. S., Gris, E. F., Tomazi, T., \& Bordignon-Luiz, M. T. (2008). Petit Suisse manufactured with cheese whey retentate and application of betalains and anthocyanins. LWT - Food Science and Technology, 41(5), 905-910. https://doi.org/10.1016/j.1wt.2007.05.019

Quigley, E. M. M. (2018). Prebiotics and probiotics in digestive health. Clinical Gastroenterology and Hepatology, 17(2), 333-344. https://doi.org/10.1016/j.cgh.2018.09.028

Ramírez-Santiago, C., Lobato-Calleros, C., Espinosa-Andrews, H., \& Vernon-Carter, E. J. (2012). Viscoelastic properties and overall sensory acceptability of reduced-fat Petit-Suisse cheese made by replacing milk fat with complex coacervate. Dairy Science \& Technology, 92(4), 383-398. https://doi.org/10.1007/s13594-012-0077-2

Renhe, I. R. T., de Souza, A. B., Francisquini, J. A., Pereira, D. B. C., Carvalho, A. F., \& Perrone, I. T. (2018). Fermentação de petit suisse obtido com retenção de soro e adição de lactase e redução da adição de açúcares versus à formulação tradicional. Revista Instituto de Laticínios Cândido Tostes, 73(1), 3742. https://doi.org/10.14295/2238-6416.v73i1.661

Roberfroid, M. B. (2005). Introducing inulin-type fructans. British Journal of Nutrition, 93(S1), S13-S25. https://doi.org/10.1079/BJN20041350

Saito, T., Martins-Madalão, M. C., Bernardes, P. C., Bosi, M. G., Della Lucia, S. M., Saraiva, S. H., \& Ibrahim Silva, P. (2019). Jabuticaba (Myrciaria cauliflora) peel extract increases bioactive compounds in petit-suisse cheese. International Food Research Journal, 26(1), $277-285$.

Sarkar, S. (2007). Potential of kefir as a dietetic beverage: A review. British Food Journal, 109(4), 280-290. https://doi.org/10.1108/00070700710736534

Sanda, K. A., Grema, H. A, Geidam, Y. A., \& Bukar-Kolo, Y. M. (2011). Pharmacological aspects of Psidium guajava: An update. International Journal of Pharmacology, 7(3), 316-324. https://doi.org/10.3923/ijp.2011.316.324

Sanders, M. E. (2008). Probiotics, definition, sources, selection, and uses. Clinical Infectious Diseases, 46(2), S58-S61. https://doi.org/10.1086/523341

Santos, T. M., Souza Filho, M. de S. M., Silva, E. de O., Silveira, M. R. S. da, Miranda, M. R. A. de, Lopes, M. M. A., \& Azeredo, H. M. C. (2018). Enhancing storage stability of guava with tannic acid-crosslinked zein coatings. Food Chemistry, 257(20), 252-258. https://doi.org/10.1016/j.foodchem.2018.03.021

Shah, N. P. (2000). Probiotic bacteria: selective enumeration and survival in dairy foods. Journal of Dairy Science, 83(4), 894-907. https://doi.org/10.3168/jds.S0022-0302(00)74953-8

Shoaib, M., Shehzad, A., Omar, M., Rakha, A., Raza, H., Sharif, H. R., Shakeel, A., Ansari, A., \& Niazi, S. (2016). Inulin: Properties, health benefits and food applications. Carbohydrate Polymers, 147(13), 444-454. https://doi.org/10.1016/j.carbpol.2016.04.020

Silva, F. A. S. (2014). ASSISTAT-Assistência Estatística-versão 7.7 beta (pt). Programa computacional. Universidade Federal de Campina Grande Campus de Campina Grande-PB-DEAG/CTRN.

Schroeder W. A., \& Johnson E. A. (1995). Singlet oxygen and peroxyl radicals regulate carotenoid biosynthesis in Phaffia rhodozyma. Journal of Biological Chemistry, 270(31), 18374-18379. https://doi.org/10.1074/jbc.270.31.18374 
Research, Society and Development, v. 10, n. 8, e7010817139, 2021

(CC BY 4.0) | ISSN 2525-3409 | DOI: http://dx.doi.org/10.33448/rsd-v10i8.17139

Teijeiro, M., Pérez, P. F., De Antoni, G. L., \& Golowczyc, M. A. (2018). Suitability of kefir powder production using spray drying. Food Research International, 112(10), 169-174. https://doi.org/10.1016/j.foodres.2018.06.023

Thaipong, K., Boonprakob, U., Crosby, K., Cisneros-Zevallos, L., \& Byrne, D. H. (2006). Comparison of ABTS, DPPH, FRAP, and ORAC assays for estimating antioxidant activity from guava fruit extracts. Journal of Food Composition and Analysis, 19(6-7), 669-675. https://doi.org/10.1016/j.jfca.2006.01.003

Tiwari, A., Sharma, H. K., Kumar, N., \& Kaur, M. (2015). The effect of inulin as a fat replacer on the quality of low-fat ice cream. International Journal of Dairy Technology, 68(3), 374-380. https://doi.org/10.1111/1471-0307.12176

Yerlikaya, O. (2019). Probiotic potential and biochemical and technological properties of Lactococcus lactis ssp. lactis strains isolated from raw milk and kefir grains. Journal of Dairy Science, 102(1), 124-134. https://doi.org/10.3168/jds.2018-14983 